\title{
О различии значений пороговых характеристик многоэлементных фотодиодных ФПУ, определенных в экспериментах с однородной модулированной засветкой фотоприемника и в экспериментах с малым (“пиксельным") пятном засветки
}

\author{
В.А. Стучинский, А.В. Вишняков, Г.Ю. Сидоров \\ Институт физики полупроводников им. А.В. Ржанова СО РАН, \\ Новосибирск, 630090, пр. Ак. Лаврентьева, 13 \\ тел:+7 (383) 333-2276, факс+7 (383) 333-2276, эл. почта: stuchin@isp.nsc.ru
}

DOI 10.34077/RCSP2019-151

В работе [1] сообщалось о различии величин минимального детектируемого (порогового) светового потока $I_{\text {пор }}$ определенных с использованием двух методик измерения, а именно: в экспериментах с модулированной однородной засветкой фотоприемника и в экспериментах, использующих локальное пятно засветки с размерами, близкими к размеру его фоточувствительного элемента (ФЧЭ). Утверждалось, что найденная во втором случае величина $I_{\text {nор }}$ превышает таковую при однородной засветке, причем в случае линейчатых ФПУ (ЛФПУ) с временной задержкой накопления (В3Н) указанное различие может достигать трех раз.

В настоящей работе была предпринята попытка количественного анализа эффекта для матричных ФПУ (МФПУ) в предположении, что этот эффект мог бы быть объяснен диффузией фотогенерированных носителей заряда (НЗ) из локально освещенного ФЧЭ ФПУ в соседние фотоэлементы. Для этого методом Монте-Карло проводилось

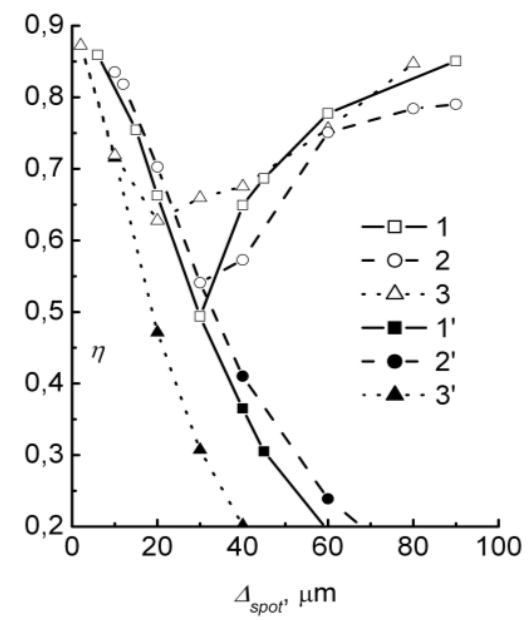

Доля частиц, стекших на диод центрального ФЧЭ, из числа частиц, рожденных в пределах центрального ФЧЭ (кривые 1 - 3) и из числа всех частиц, рожденных в слое абсорбера (кривые 1'-3'). Кривые 1 и 1', 2 и 2', и 3 и $3^{\prime}$ соответствуют квадратному, круглому и гауссову пятнам засветки. моделирование диффузии ФНЗ из центрированных на ФЧЭ размером 30х30 мкм круглого, квадратного и гауссова пятен засветки в соседние ФЧЭ при актуальных величинах параметров задачи (геометрические размеры матрицы МФПУ, длины диффузии ФНЗ и длины поглощения излучения в фоточувствительной пленке фотоприёмника). Анализировалась зависимость от размера пятна $\Delta_{\text {spot }}$ количества частиц, стекших на фотодиод рассматриваемого ФЧЭ при его нормировке на число частиц, рожденных в пятне засветки либо на полное количество частиц, рожденных в слое абсорбера (см. рисунок).

Анализ результатов проведенных Монте-Карло расчетов позволил сделать следующие выводы:

1) При принятых значениях параметров задачи диффузия ФНЗ за пределы освещенного ФЧЭ может увеличить величину порогового детектируемого потока при освещении МФПУ пятном до $30-40 \%$ по сравнению со случаем равномерной засветки фотоприемника.

2) Нормированная на мощность излучения в пучке величина фотосигнала засвеченного ФЧЭ быстро спадает с увеличением размера пятна засветки в диапазоне 10-40 мкм; это связано с уменьшением доли пучка света в центральном пикселе. При этом для гауссова пятна с размером 30 мкм найденный пороговый поток оказывается увеличенным примерно в 3 раза по сравнению со случаем равномерной засветки матрицы. Этот результат показывает, что критически важным фактором для методики определения пороговых характеристик МФПУ с применением “пиксельной” засветки является точность покрытия пятном ФЧЭ матрицы; этот же фактор играет важную роль как определяющий различие величин пороговых потоков и для ВЗНЛФПУ.

3) В целом проведенное рассмотрение дает общий пример анализа (распространенный в работе также и на случай ВЗН-ЛФПУ), позволяющего для конкретных значений параметров задачи посредством моделирования методом Монте-Карло предсказать величины пороговых характеристик многоэлементных ФПУ, определенных с использованием локальной (“пиксельной”) засветкой фотоприёмника и его однородной засветкой.

\section{Лuтература}

[1] В.Н. Васильев и др., Успехи прикладной физики, 2015, Т. 3, № 5, С. 486-495. 